\title{
Integrity and Performance of High School Teachers in Pekanbaru
}

\author{
Isjoni*, Afrianto Daud, Azhar
}

Faculty of Teachers Training and Education Universitas Riau, Pekanbaru, Indonesia

*isjoni@yahoo.com

\begin{tabular}{l}
\hline Article Info \\
\hline Received $: 2019-01-01$ \\
Accepted : 2019-01-15 \\
Published : 2019-01-28 \\
\hline
\end{tabular}

Key words: integrity, teachers performance \begin{abstract}
This study was aimed at finding if integrity affects the performance of High School Teachers in Pekanbaru. So the hypothesis of this study is that if the integrity has an influence on the performance of high school teachers in Pekanbaru. The method used in this study was a survey with correlational techniques. This technique was carried out to analyze the influence of two independent variables $\mathrm{X}$ with dependent variables Y. The population in this study were all high school teachers (178 teachers) and the samples were teachers who had received teacher certification at the SMAN Kecamatan 121 Tenayan Raya. Data were analysed using descriptive analysis techniques and inferential analysis to test hypotheses. The requirements for analyzing the data are: normality test, homogeneity test, and linearity test. The results showed that integrity had a significant effect with a positive direction on teacher performance in the Tenayan Raya High School in Pekanbaru. This is indicated by the regression coefficient of integrity against teacher performance of 0.083 . The point is that if the integrity variable rises by one unit, an increase in teacher performance is 0.083 . Furthermore, the effect of the variable integrity on teacher performance resulted in a value of $0.69 \%$. This means that integrity contributes significantly to teacher performance by $0.69 \%$. This contribution is in the very low category. Therefore, it can be concluded that integrity has a positive and significant effect on teachers' performance in Tenayan Raya High School.
\end{abstract}

\section{Introduction}

Teachers are required to have a performance that is able to provide and realize the hopes and desires of all parties, especially the general public who have trusted the school and teachers in fostering students. Achieving good quality education is strongly influenced by the performance of teachers in carrying out their duties so that teacher performance becomes an essential demand for achieving educational success. In general, good quality education is a benchmark for the success of the performance shown by the teachers.

Teachers who have good performance will always be fully aware of their responsibilities and try to carry out well all the tasks given to them in accordance with the ability they have to get maximum work results. On the contrary, if a teacher does not have a good performance, it will only give a negative impact on the teacher himself and the school where he works. Teachers are the main key in the education system, so improving the performance of a teacher really needs to be done both individually and in groups as an effort to improve better outcomes.

Based on the description of the background explained above, this study is aimed at answering the following reseach question: Does integrity affect the performance of high school teachers in Pekanbaru city? 


\section{Literature Review}

Performance has been describe in similar perspectives by some scholars. Fatah (1996), for instance, affirms that performance is interpreted as an expression of progress based on knowledge, attitudes and motivation in producing work. Hasibuan (2007) states that performance is a result of work achieved by someone in carrying out tasks assigned to him based on skills, experience, sincerity and time. This implies that teacher performance can be interpreted as the results achieved by the teacher for the implementation of professional and functional duties in the learning that has been determined in a certain period of time. Dunda states that teacher performance can be assessed from the basic aspects of the ability that should be possessed by a teacher known as "teacher competence".

Performance reflects the success of an organization, then it is considered important to measure the characteristics of the workforce. Teacher performance is the culmination of three interrelated elements, namely skills, efforts of condition characteristics and external conditions. Skill level is the raw material that someone brings to work such as experience, ability, interpersonal skills and technical skills (Engkay Karweti, 2010).

According to Mangkunegara (2009), a performance (work performance) is the work result in the quality and quantity achieved by an employee in carrying out his duties in accordance with the responsibilities given to him. The quality aspect refers to the perfection and neatness of the work that has been completed, while the quantity refers to the workload or work target in completing the work.

Teacher performance is a result achieved by a teacher through his work or in other words, the teacher's performance is the work achievement of a teacher. Djojonegoro (1996: 13) argues that if the teacher's performance does not concern us together, we should never hope that there will be a change in our educational practices in this country because I strongly believe that teachers are the determining factor for the success of our education.

Sianipar (1999: 12) proposes four main performance management activities that must be carried out in an integrated manner, namely: 1) performance planning, 2) performance management, 3) performance review, and 4) appreciation for performance. Assessment of a teacher's performance is a very important part of the entire process of the teacher's performance. Assessment itself is a process where the organization seeks to obtain information as accurately as possible about the performance of its members. Assessment is carried out to determine the level of teacher performance. According to Martinis Yamin and Maisah (in Hary Susanto, 2012) several sources of assessment of education personnel are: (1) self-assessment; (2) assessment by students; (3) peer review; and (4) assessment by direct supervisor.

From the above opinions, it can be drawn a synthesis that the teacher's performance is the level of success achieved by the teacher in carrying out and completing tasks assigned to him in accordance with the responsibility to achieve the stated goals, with indicators: (1) pedagogic, (2) personality, (3) social, and (4) professional.

According to Sihombing, teacher performance is influenced by three factors: 1) competency (ability) and academic qualifications; 2) factors of academic supervision or education services by supervisors; 3) factors of personality, attitudes and motivations. These three factors will influence teachers behavior to produce good and quality performance in the learning process carried out in the classroom.

According to Mangkunegara (in Purnama Sejati), indicators of performance/'work performance' assessments are as follows:

a) Work quality 
Quality of work is seen from an understanding of the scope of work, job descriptions, responsibilities and authority carried out.

b) Work quantity

The quantity of work is shown through results and speed in carrying out the work.

c) Employee Consistency

Consistency is seen from the effort to always develop abilities and self-actualization, understand and follow the instructions given, have initiative, honesty, intelligence, and prudence in working.

d) Teamwork

Teamwork is the ability to work together shown to improve quality.

e) Employee Attitude

Attitude is behavior towards organization / institution or superior and also co-worker.

Integrity can be seen as the depth and expansion of emotional honesty where emotions and lust themselves are intuitive considerations of the most important kinds, and from here integrity is born and upheld. In addition, it is through intuitive awareness and strong inward direction towards integrity that we can create creativity and pride. Besides, the possibility of integrity is interactional in which it involves managing relationships between people and others in the surrounding (Elvira Zahra, 2011).

Teacher integrity also influences teacher behavior. Teacher behavior is a variety of teacher activities related to things that must be done, especially activities related to guidance and direction in learning. According to Arikunto, teacher integrity is influenced by various factors, including: loyalty, obedience, responsibility, honesty, cooperation, and initiative.

Based on the definitions stated above, it can be said that teacher integrity is the level of honesty, oral commitment and the desire and effort of the teacher to be a complete and integrated person in carrying out his or her duties properly. The integrity of a teacher is very influential in the success of learning. This was revealed by Parmer $(1998$, p. 10)) in his book the Courage to Teach stating that "good teaching cannot be reduced to technique, good teaching comes from the identity and integrity of the teacher".

In his book, Palmer believes that good teaching is not produced by a good technique, but by a teacher with integrity. Teachers with integrity can unite themselves, their lessons and students as a series of learning. It is like a person in weaving, a teacher with integrity can unite complex things in a unity whose manifestations can be seen in his life. The main task of a teacher is to develop student potentials to the fullest through the presentation of subjects. Each subject, behind the material delivered, also has certain values and characteristics that underlie the material. Therefore, the task of a teacher in addition to presenting the material is that the teacher is also responsible for developing the character and underlying characteristics in the subject. To carry out this task, the teacher must have integrity that is expected to support the implementation of his duties in learning.

A teacher who has integrity is reflected both in his attitude and daily behavior when teaching, interacting with students, colleagues or people. Some attitudes that reflect a teacher having good integrity as stated by Suparno (2015) include: 1. Having academic honesty, 2. Continuing to learn to become professional 3. Developing SQ, EQ, and IQ in life 4. Responsible in assignments and call 5. Timely and keeping promises 6. Consistent with what he says and thinks, 7. Consequent with what he does 8. Being open to friends 9. Always reflecting on what he has done 10. Building relationships with God 11. Making sure that what he does does not violate the code of ethics 12 . Exemplary and having integrity 13. Dare to admonish each other 
and reveal irregularities, 14. Honest between teachers and students 15. Dare to admit mistakes 16. Dare to be honest.

\section{Research Methodology}

This research was carried out in Senior High Schools in Pekanbaru City. The research began in May 2018 to September 2018. The method used in this study was a survey method with correlational techniques. This technique was carried out to analyze the influence of two independent variables $\mathrm{X}$ with dependent variables $\mathrm{Y}$.

The population in this study were all 178 Senior High School teachers and the sample was the teachers who had received teacher certification at Senior High School Tenayan Raya Subdistrict as many as 121 people. Based on the variables studied as seen in the problem constellation model before, the data in this research were collected by distributing questionnaires for integrity variables, while for teacher performance variables, they were obtained through documentation from the Principal.

The data analysis techniques used to process the data in this study were descriptive analysis techniques and inferential analysis. Descriptive analysis was used to provide an overview of the frequency distribution of the data histograms, modes, medians, mean values, and standard deviations. Inferential statistical analysis was used to test hypotheses that have been formulated before. Before testing the hypothesis in this study, first the requirements of data analysis were tested. The requirements for analyzing the data were: normality test, homogeneity test, and linearity test.

\section{Findings and Discussion}

Validity test is used to determine the feasibility of the items used. Furthermore, the validity test used on integrity $(\mathrm{X})$, at a significant level of $\alpha=0.05, \mathrm{n}=33$ people, and the rtable value $=$ 0.364 is if the value of rcalculated > rtable value then the item statement is valid, and if the value of rcalculated < rtable value, then the statement item is invalid. On the integrity instruments made as many as 30 items, after the item validity had been calculated, there were 28 valid statements and 2 invalid statement items (items 19 and 25). Furthermore, the reliability of Integrity $(\mathrm{X})$ instrument was tested with valid reliability obtained a value of 0.906 .

The normality test of the data in this study used the Kolmogorov_smirnov test, with a significant level used as a rule to accept or reject testing for normality or the presence or absence of a data distribution $\alpha=0.05$. To accept or reject the hypothesis was done by comparing the significant value of the variable with $\alpha=0.05$. As for the decision rule, the data is declared to be normally distributed if a significant value $>\alpha=0.05$. The following are the normality testing data of the three research variables.

Based on the normality test using the Kolmogorov-Smirnov Test, the KSZ values are 0.669 and Asymp. Sig. for 0.766 is greater than 0.05, it can be concluded that the data are normally distributed. For the homogeneity test, data can be said homogeneous if sig $>0.05$ and not homogeneous if sig $<0.05$. It is seen that sig $=0.154>0.05$ which indicates that the data of the variable Integrity $(\mathrm{X})$ on Teacher Performance $(\mathrm{Y})$ are homogeneous.

Significant value $=0.03$ is smaller than 0.05 , which means the data are linearly significant between the variable Integrity $(\mathrm{X})$ on the variable Teacher Performance $(\mathrm{Y})$.

The research data consist of two variables: one dependent variable and one independent variable. The dependent variable (Y) is Teacher Performance, while the independent variable $(\mathrm{X})$ is Integrity. The data obtained from the research findings are presented as follows:

The results of the documentation data obtained from the Head of the Tenayan Raya Subdistrict High Schools are the results of the calculation of indicators of the Teacher 
Performance variable (Y) according to the Minister of National Education Regulation No. 35 of 2010 which are about Pedagogics, Personality, Social and Professional.

The calculated data show that the standard deviation of pedagogic is 1,849 . This number is far below the pedagogic average of 25.09. This means that the data distribution of teacher performance on pedagogy is quite homogeneous. PNS (Civil Servant) teachers who have pedagogical competencies below the average are 54 people or $49 \%$. That is, the Senior High School teachers in Kecamatan Tenayan Raya have medium category pedagogical competencies. Meanwhile, there are 58 PNS teachers who have pedagogical competencies above the average or $52 \%$.

The calculated data show that the standard deviation of personality is 1.342 . This number is far below the personality average of 10.59. It means that the data distribution of teacher performance on personality is quite homogeneous. Civil servant teachers who have below average on personality competence are 51 people or $47 \%$. This means that the Senior High School teachers in Tenayan Raya Subdistrict have medium category personality competencies. Whereas, there are 58 PNS teachers who have personality competencies above the average or $53 \%$.

The calculated data also show that the standard deviation of social competency is 0.885 . This number is below the social average of 6.42, meaning that the data distribution of teacher performance on social competency is homogeneous. Civil servant teachers who have below average social competence are as many as 57 people or $52 \%$. This means that the civil servant teachers in Tenayan Raya Subdistrict have moderate category social competencies. Meanwhile, there are 52 PNS teachers who have social competence above the average or $48 \%$.

The calculated data show that the standard deviation of professional competency is 1.082. This number is still below the professional average of 5.84, meaning that the data distribution of teacher performance on professional competence is quite homogeneous. The Senior High School teachers who have professional competence below the average are 50 people or $46 \%$. This means that the Senior High School teachers in Tenayan Raya Subdistrict have professional competencies in the medium category. Meanwhile, there are 61 civil servant teachers who have professional competence above the average or $54 \%$.

Based on the results of the calculation of the overall data teacher performance, it is obtained that the lowest empirical score achieved by respondents is 40 and the highest score is 56. Thus, the range of empirical scores is equal to 14 . The calculation of the distribution of teacher performance scores results: (1) average score $=47.94$, (2) middle score $=48.00$ (3) mode score $=48$ and (4) standard deviation score $=3.153$.

Based on the summary of teacher performance, it is explained that the average value, middle value and mode score are located in the same position and close to each other (47.94: $48.00 ; 48)$, thus it is concluded that the Teacher Performance variable is normally distributed. Furthermore, the distribution of teacher performance scores at Senior High Schools in Tenayan Raya Subdistrict is presented in a frequency distribution list with a total of 4 categories: moderate, sufficient, good, and very good, based on the conversion of the performance scores of teacher PK results on a scale of 14-56.

Based on the processed data, the distribution of teacher performance variable scores at Senior High Schools in Tenayan Raya Subdistrict explains that 5 respondents with a percentage of $4.59 \%$ are categorized sufficient, 83 respondents with a percentage of $74.31 \%$ are categorized good, and 28 respondents with a percentage of $21.10 \%$ are categorized very good. Thus, it can be concluded that the performance of the Senior High School teachers of Tenayan Raya Subdistrict in Pekanbaru City is good. 
Based on the results of the calculation of Integrity data, it is obtained that the lowest empirical score obtained by the respondents is 71 and the highest score is 110 . Thus, the range of empirical scores is 39. The calculations on the distribution of teacher integrity scores result in: (1) average score $=86.94$ (2) middle score $=87$, (3) mode score $=87$, and (4) standard deviation score $=7.816$.

Based on the data processing and analysis, it is shown that the mean, median and mode scores are located in the same position and close to each others $(86.94 ; 87.00 ; 87)$, thus it is concluded that the Integrity variable is normally distributed. Based on the data processing and analysis, it is shown that the distribution of the integrity variable scores at Senior High Schools in Tenayan Raya Subdistrict explains that 19 respondents with a percentage of $15.60 \%$ are categorized in the moderate category, 79 respondents with a percentage of $70.64 \%$ are categorized in the high category and 24 respondents with a percentage of $13.76 \%$ are categorized in the very high category. Thus, it can be concluded that the integrity of the Senior High School teachers at Tenayan Raya Subdistrict in Pekanbaru City is high. Based on the hypothesis on the theoretical framework, the hypothesis testing that will be carried out is: Integrity (X) influences Teacher Performance (Y).

The result of the test shows that integrity has a significant effect with a positive direction on the Performance of the Senior High School teachers in Tenayan Raya Subdistrict in Pekanbaru City with a significant influence of $0.69 \%$. The results show that integrity has a significant influence with a positive direction on teacher performance in the Senior High Schools of Tenayan Raya Subdistrict in Pekanbaru City. This is indicated by the regression coefficient of integrity on teacher performance 0.083 . The point is that if the integrity variable rises by one unit, then an increase in teacher performance is 0.083 . Furthermore, the effect of the variable integrity on teacher performance results in a value of $0.69 \%$. This means that integrity contributes significantly to teacher performance by $0.69 \%$. This contribution is in the very low category.

In line with the views by Triguna (2001) stating that integrity is the fruit of work, integrity is not only a good idea, but a strong feeling based on a set of its own created working principles. Integrity can be a goal actualized in various ways that are good, effective, and efficient. Such conditions are very beneficial in achieving individual and management success. The results of this study are also in accordance with Antonius (2014) opinion saying that integrity encourages the achievement of good results in the form of good performance or achievement of good things in life.

The results of this study are in accordance with the research conducted by Jonter saying that teachers who have high integrity in working will be easier to manage a pleasant working atmosphere, so that it can improve teacher performance better.

\section{Conclusions and Recommendations}

From the results of this study, it can be concluded that: Integrity has a positive and significant effect on Teacher Performance at Senior High Schools in Tenayan Raya Subdistrict in Pekanbaru. Based on the conclusions of this research, teachers are expected to increase specific training on how to improve performance by intensifying activities that can improve performance. Then, Education and Culture Office of Riau Province is expected to always provide enrichment to schools. This is very important, because it can contribute to the progress of schools in Pekanbaru, especially to increase knowledge for teachers. 


\section{References}

Anggraeni, N. (2012). Pengaruh Kemampuan dan Motivasi terhadap Kinerja Pegawai pada Sekolah Tinggi Seni Indonesia (STSI) Bandung. Jurnal ISSN 1412-565X.

Atoshoki, G. A. (2014). Integritas Personal dan Kepemimpinan Etis. Jurnal Humaniora, 5 (2).

Badrudin. (2014). Pengaruh Supervisi dan Motivasi Kerja terhadap Kinerja Guru pada MTs Negeri Anyar Kabupaten Serang Propinsi Banten. Jurnal Reformasi Administrasi, 1(1).

Barinto. (2012). Hubungan Kompetensi Guru dan Supervisi Akademik dengan Kinerja Guru SMP Negeri Se-Kecamatan Percut Sei Tuan. Jurnal Tabularasa PPs UNIMED.

Fatimah, D., \& Khairuddin. (2015). Komunikasi Kepala Sekolah dalam Meningkatkan Kinerja Guru pada SMA Negeri 1 geumpang Kabupaten Pidie. Jurnal Administrasi Pendidikan, 3(4).

Karweti, E. (2010). Pengaruh Kemampuan Manajerial Kepala Sekolah dan Faktor yang Mempengaruhi Motivasi Kerja terhadap Kinerja Guru SLB di Kabupaten Subang. Jurnal Penelitian Pendidikan, 11(2).

Mangkunegara. (2009). Manajemen Sumber Daya Manusia Perusahaan. Bandung: PT. Remaja Rosda Karya.

Palmer, P. J. (1998). The courage to teach: exploring the inner landscape of a teacher's life. San Francisco, Calif: Jossey-Bass.

Sejati, P. Hubungan Motivasi Kerja dengan Prestasi Kerja Guru dan Karyawan di SMK Muhammadiyah 1 Sleman. Jurnal.

Suarna, I Made, dan kawan-kawan. (2013). Determinasi Kepemimpinan Kepala Sekolah, Supervisi Akademik dan Sikap Guru terhadap Profesinya dengan Kinerja Guru SD Negeri Gugus II di Kecamatan Melaya, Kabupaten Jembrana. E-Journal Program Pascasarjana Universitas Pendidikan Ganesha, 3.

Suhardan, D. (2010). Supervisi Profesional. Bandung: Alfabeta.

Sulistyorini, 2001. Hubungan antara Keterampilan Manajerial Kepala Sekolah dan Iklim Organisasi dengan Kinerja Guru. Ilmu Pendidikan, 28(1), 62-70.

Sumihar, S. S. (2014). Meningkatkan Kinerja Guru Biologi SMA Negeri dalam Pembelajaran melalui Supervisi Klinis. Jurnal Manajemen Pendidikan Indonesia, 6(2).

Susanto, H. (2012). Faktor-faktor yang Mempengaruhi Kinerja Guru SMK Negeri 1 Daha Selatan Kab. Hulu Sungai Selatan Kal-Sel. Jurnal Pendidikan Vokasi, 2(2).

Suwardi. (2009). Hubungan Guru terhadap Supervisi Klinis dan Bantuan Supervisor dengan Kinerja Guru SMA Negeri di Kabupaten Magelang. Surakarta: Tesis Pascasarjana Universitas Sebelas Maret.

Yogaswara, A. (2010). Kontribusi Manajerial Kepala Sekolah dan Sistem Informasi Kepegawaian terhadap Kinerja Mengajar Guru. Jurnal Penelitian Pendidikan, 1 (2). 